\title{
Exploratory study of a crisis commander's perspectives on the role and value of public relations in crisis management
}

\author{
Saidathul Nizah Mat Tazin ${ }^{1, *}$, and Kiranjit Kaur ${ }^{2}$ \\ ${ }^{1}$ Public Relations Department, Faculty of Communication and Media Studies, Universiti Teknologi \\ MARA, 40450, Shah Alam, Malaysia \\ ${ }^{2}$ Public Relations Department, Faculty of Communication and Media Studies, Universiti Teknologi \\ MARA, 40450, Shah Alam, Malaysia
}

\begin{abstract}
This is an exploratory study into understanding the dominant coalition perspectives on role and values of public relations in crisis management in an energy company in Malaysia. In this study, the senior public relations of the energy company reports directly to the crisis commander (CC) in times of crisis thus, the $\mathrm{CC}$ was chosen as a sample where an in-depth interview was conducted. Notably, the CC perceptions represents the dominant coalition with the power to shape organisation policies and provide directions to public relations practice in managing media and communication in crisis management. Theory of excellence within the outlook of public relations empowerment was examined. The findings of this study have significantly confirmed that the patterns of the $\mathrm{CC}$ perceptions on role and values of public relations in crisis management are similar to other dominant coalition literature across the globe. This phenomenon needs changes to drive public relations to strive harder to be a problem solver and a strategic thinker in crisis management. This study is a significant attempt to understand the perception of the dominant coalition on public relations in crisis management and can be replicated in other sectors in Malaysia.
\end{abstract}

\section{Introduction}

The public relations role as a boundary spanner becomes significant in crisis management for trust building when there is constant communication with the society during crisis phases (pre, during and post). Public relations counsel to the dominant coalition contributes to the intention and action of accountability, transparency and integrity of organisational response in crisis management. Nevertheless, public relations dilemma in crisis management is prevalent when they became less influential with the dominant coalition. This study looks into the value of public relations from the viewpoint of a crisis commander (CC) in an energy sector in Malaysia. It is one of few attempts to examine public relations significance from the perspective of a member of a dominant coalition in crisis management in Malaysia.

*Corresponding author: saidathul06@yahoo.com 


\section{Literature review}

Public relations literature $[1,2]$ emphasizes the public relations managerial function to be influential in decision-making in crisis management. Public relations as a managerial function plays a crucial role as a problem-solving facilitator engaging in environmental scanning and monitoring to identify issues and then adjust to the organization's mission to avoid conflict. However, public relations role engaging in a symmetrical communication model was critised by scholars for being unrealistic [3] and has limits especially in times of crisis [4]. Notably, public relations is based on ethical worldview that describes the normative standard of the practice.

Research is central to public relations practice $[5,6,7]$ before having the credibility to advise dominant coalition to provide an ethical response in times of crisis. Public relations constructive role in crisis management also relies on communication planning [8], public relations function within organization and experiences managing crisis [9] and being practical, realistic and pragmatic in times of crisis [10]

Regardless of the multiple factors for public relations to be influential in crisis management, public relations significance in crisis management is dependent on the dominant coalition control and understanding over public relations value in crisis management. In other words, public relations empowerment is dependent on the power of dominant coalition who gives direction to public relations practice in organisations [11]. Relying on technical communication skills alone does not promise a successfully managed crisis without communication autonomy granted to public relations [12]. Grunig believes when the senior public relations is a member of dominant coalition, it helps organization manage its strategic public and achieve goals to become effective [13]. However, public relations has to extend its expertise as boundary spanners in various skills, resources, strategies, tactics and experiences to be accepted as member of the dominant coalition $[14,15]$. Public relations advises on ethical implications and maintenance of dialogic communication and relationships with publics is important to create ethical organizational behaviour [16] thus, manage public relationship for reputation.

Public relations role in managing crisis communication is growing in all parts of the world. Crisis communication practice focuses on public relations theoretical framework at large [17] where managing information at three different phases; pre, during and after a crisis is necessary [18]. In pre-crisis phases of previous organizational crisis experiences, it observed public relations involvement in strategic management managing communication in times of crisis [19].

The researchers employed the generic principles of Excellence theory and looked into public relations empowerment. This theory guides the researcher to understand the public relations role and value in crisis management in the dominant coalition perspectives. Besides, it is an added value research to study the excellence theory in terms of crisis management in Malaysia.

This paper asks two research questions. First, how does the dominant coalition perceive the public relations role in crisis management in the energy company in Malaysia? And, second, how does the dominant coalition perceive the value of public relations in the crisis management of the energy company in Malaysia?

\section{Methodology}

This study was conducted in a government-linked energy company in Malaysia due to its experiences managing multiple crises since 1980s till 2005. The global changing environment continues to threaten the energy company in Malaysia with multiple types of crises including financial, technological, natural, skewed management values and deception 
that may tarnish the organisational reputation and jeopardise the economy of the country. A single-case design was employed to understand the real context of the public relations practice in managing crisis communication in this particular energy company [20, 21].

An in-depth interview was conducted with the Crisis Commander (CC), who has the next highest position after the CEO in the hierarchy of ERP and chairs the Corporate Emergency Response Plan (CERP) steering committee in the energy company. The senior public relations reports directly to the $\mathrm{CC}$. The interview was held for one hour with data being taped and transcribed. To avoid biases, the researcher uses epoche [22], a Greek word meaning to refrain from judgement [23]

\section{Findings}

The results of this study were discussed according to the research questions.

\subsection{Dominant coalition's perception of the public relations role in crisis management in the energy company in Malaysia}

According to the crisis commander (CC), the senior public relations manager plays a role as communication and media adviser in crisis management at two levels; in the strategic planning team, and the Emergency Response Plan (ERP) team. While on-going advice on communication is managed by the strategic planning team, specific communication advice is conducted in the ERP team during a crisis. The communication processes and procedures during a crisis are explained to guide the ERP team to communicate effectively to stakeholders. The senior public relations manager advices the CEO on guidelines for communicating with public figures in times of crisis with regard to the nature of the crisis encountered. The senior public relations manager also determines the appropriate time for the $\mathrm{CEO}$ or $\mathrm{CC}$ to make a public appearance and to respond accurately in press conferences. The $\mathrm{CC}$ admitted that public relations advice in managing media in times of crisis is essential because failure to do so may lead the media to "pick one of you and make you look horrible."

\subsection{Dominant coalition's perception on the value of public relations in the crisis management of the energy company in Malaysia}

\subsubsection{Value of public relations in perception management}

The dominant coalition trusts public relations to manage stakeholder perceptions as ongoing process of crisis communication. According to the $\mathrm{CC}$, "the value of public relations in managing perceptions is equally crucial to making the business sound." Ineffective management of stakeholder perception leads to failure to communicate with the parties concerned and it is the main risk of the company. However, the CC believes effective communication is the best strategy to manage stakeholder perception. Thus, public relations is expected to disseminate information about energy businesses and objectives to avoid misunderstanding. The CC said communication is effective when public disregards negative news and perceives only favourable news despite the crisis. The dominant coalition understands that managing smouldering issues are among the challenges met in managing perceptions in the energy company. Nevertheless, the CC said, "you cannot expect praises from everybody, but at least, people would say, nobody wanted the crisis to happen, but this company managed it well. So this is what we want 
at the end of the day." The dominant coalition believes there is room for improvement for public relations in management of perceptions.

\subsubsection{Value of public relations in trust building}

The dominant coalition of the energy company believes that the company is trusted because of its brand. The basis of this confidence is generated by competent electricity supply and efficient programmes. While the technical feature engages the engineers for trust building through effective delivery of products and services, the value of public support is measured by the efforts of corporate responsibility, philanthropy, strategic communication and media relations to build trust with stakeholders. The dominant coalition appreciates the role of public relations in educating the public; from consumers to school children, contractors and developers on the issue of electricity safety awareness.

Public relations efforts in educating multiple publics have raised the level of trust among its stakeholders for the energy company. The dominant coalition acknowledged that the public relations efforts increases the public understanding of the nature of the energy business and minimises difficulties in managing organisational response at any point in time. Similarly, other effective programmes including media night, sports tournament and donation drives support the energy power to promote familiarity with its stakeholders.

\section{Discussion}

The findings of the first research question presented that the $\mathrm{CC}$ of the energy power recognises the senior public relations manager as a member of the crisis management team along with other core divisions of the energy company, advising on communication and media. The role of senior public relations as media and communication counsel is a continuous one in strategic planning team and recognised most only during a crisis in the ERP team. The senior public relations manager continues to perform more of a technical function especially as media relations specialist and communication liaison. The senior public relations role gain power only when the position has a hierarchical authority, control of the environment (research) and network centrality [24]

The findings of the second research question described the dominant coalition's perception of the value of public relations in crisis management in perception management and trust building strategies and it is restricted to media relations activities and communication programmes. The dominant coalition has a poor perception of public relations commitment in research activities, monitoring and scanning of the environment. Formative research is crucial to gather information about public opinion and issues focusing an organisation and prepares the organisation for managing crisis and to minimise reputation damages.

\section{Limitation}

This paper focuses only on a single case study with a limited sample size. Nevertheless, the findings obtained are significant and contribute to future research. Future studies can expand the type of organisation involved with multiple sample size.

\section{Conclusion}

Research on public relations practice in various sectors in Malaysia needs to be expanded to improve the perception of the dominant coalition towards the profession. Public relations 
should not be complacent and rely only on skills and technical functions in crisis management but to conduct more formative research activities and expand the problemsolving function.

\section{References}

1. Grunig, J. E. Excellence in public relations and communication management. (1992)

2. Grunig, Larissa. A., Grunig, J.E., \& Dozier, D.M. Excellent public relations and effective organizations: A study of communication management in threes countries. (2002)

3. Van der Meiden. Int. PR Review. 16, 3 (1993)

4. Leitchy. PR Review 23, (1997)

5. Cutlip S.M., Center A.H., \& Broom G.M. Effective public relations. (2006)

6. Vercic, D \& Grunig, J.E. Perspectives on public relations research. (2000)

7. White, J., \& Dozier, D.M. Public relations and management decision making. Excellence in public relations and communication management (1992)

8. Reber, B.H \& Berger, B.K. J. Comm Mgt. 10, 3, (2006)

9. Guth, D.W. PR Review. 21, (1995)

10. David, P. J. PR Research. 16, (2004)

11. Rhee, Y. The employee-public-organization chain in relationship management: A case study of a government organization. (2004).

12. Marra, F. J. PR Review. 24 (4), (1998).

13. Grunig, Larissa. A., Grunig, J.E., \& Ehling, W.P. What is an effective organization. Excellence public relations and communication management. (1992).

14. Berger, B.K. Public relations and organizational power. The future of excellence in public relations and communication management. (2007)

15. Pritchard, R.S., Davis, D \& Filak, V.F. The impact of the dominant coalition on health care public relations practitioners. http://www.instituteforpr.org/wpcontent/uploads/ImpactDominantCoalition.pdf

16. Bowen, Shannon. A. J. Comm Mgt. 10, 4 (2006)

17. Fearn-Banks, K. Crisis communications: A case approach.(2011).

18. Coombs, W.T. \& Holladay, S.J. Handbook of crisis communication. (2010)

19. Fearn-Banks, K. Crisis communications: A review of some best practices. In Heath, R.L (Ed) \& Vasquez, G (Contr.Ed), Handbook of public relations. (2001).

20. Yin, R.K. Qualitative research from start to finish. (2011)

21. Yin, R.K. Applications of case study research. (2012)

22. Merriam, S.B. Qualitative research: A guide to design and implementation. (2010)

23. Wimmer \& Dominick. Mass media research: An introduction. (2006)

24. Dozier, David. M \& Grunig, L.A. The organizational roles of communications and public relations practitioners. Excellence public relations and communication management. (1992) 